\title{
Salvage of an Infected Below-Knee Amputation with Chlorhexidine and Bi-Layer Dermal Matrix: A Case Report
}

\author{
Hunter R. Moyer ${ }^{1-3}$ and Jon Minter ${ }^{4}$
}

\begin{abstract}
Background: Salvage of below-knee amputations is of utmost importance as studies have shown dramatically improved ambulation rates and overall outcomes. Multiple techniques of BKA stump preservation have been described in the literature, from conservative management to free tissue transfer, each with differing success and complication rates.

Method: We present a staged treatment of a grossly infected BKA stump with minimal soft tissue coverage using aggressive debridement, intravenous antibiotics, chlorhexidine immersion, and staged bi-layer dermal matrix placement with interval split thickness skin grafting.

Results: The patient is now twelve-months out from surgery and ambulating on a below-knee prosthetic limb without the need to replace the prosthetic limb.

Conclusion: The adoption of chlorhexidine irrigation to the clinical algorithm has greatly aided in eradication of infection, dermal matrix engraftment and salvage of lower extremity wounds.
\end{abstract}

A PPROXIMATELY 75,000 AMPUTATIONS are performed annually in the United States, and $70 \%$ of these are performed as below-knee (trans-tibial) amputations (BKAs) [1]. Over half of all amputations are a result of vascular disease, either diabetic in nature or peripheral arterial disease, and only $2 \%$ are a result of cancer.

Despite greater complication rates with BKAs [2], including up to a five-fold greater infection rate and two-fold greater reoperation rate, BKAs are associated with greater ambulatory rates then above-knee amputations (AKAs) partially because of less energy consumption in gate [3]. Therefore, aggressive attempts often are made to preserve the knee when planning an amputation intervention. The blood flow to more distal flaps is one major complicating factor that leads to wound breakdown and infection in BKAs. Most series show a 10\%-15\% conversion rate from BKAs to AKAs, and these patients universally are found to have poor ambulation rates [1,2].

Salvage of BKAs is of utmost importance as studies have shown dramatically improved ambulation rates and overall outcomes. ${ }^{4}$ Multiple techniques of BKA stump preservation have been described in the literature, from conservative management to free tissue transfer, each with differing success and complication rates. We present a staged treatment of a grossly infected BKA stump with minimal soft tissue coverage using aggressive debridement, chlorhexidine immersion, and staged bi-layer dermal matrix placement (Integra LifeSciences Corporation, Plainsboro, NJ) with interval split thickness skin grafting. The patient is now twelve months out from surgery and ambulating on a below-knee prosthetic limb without the need to replace the prosthetic limb.

\section{Case Report}

The patient is a 70-year-old Caucasian male who suffered initially a crush injury to his right lower leg in 1993. Initially, he underwent operative reduction and internal fixation, but infection ensued. The hardware subsequently was removed with delayed placement of bone grafts because of the initial post-operative infection. Of note, the patient also suffers from coronary artery disease and severe rheumatoid arthritis for

\footnotetext{
${ }^{1}$ Atlanta Plastic Surgery, Atlanta, Georgia.

${ }^{2}$ Division of Plastic Surgery, Emory University Atlanta, Georgia.

${ }^{3}$ Department of Biomedical Engineering, The Georgia Institute of Technology, Atlanta, Georgia.

${ }^{4}$ Northside Total Joint Specialists, Cumming, Georgia.
}

(c) Hunter R. Moyer and Jon Minter 2016; Published by Mary Ann Liebert, Inc. This Open Access article is distributed under the terms of the Creative Commons License (http://creativecommons.org/licenses/by/4.0), which permits unrestricted use, distribution, and reproduction in any medium, provided the original work is properly credited. 


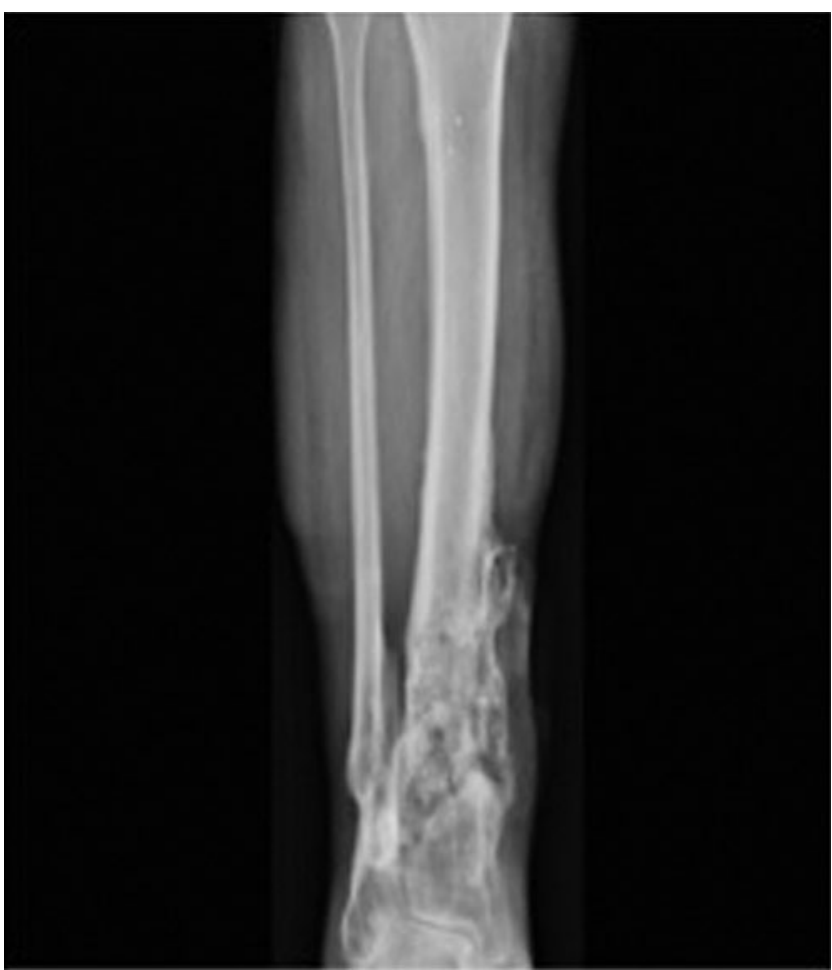

FIG. 1. Radiograph demonstrating signs of chronic osteomyelitis.

which he takes daily prednisone. Since this initial injury, he has been treated on a recurrent basis by an infectious disease team for chronic osteomyelitis and draining sinus tracts (Fig. 1). Intermittent cultures were positive for Escherichia coli and Pseudomonas aeruginosa. The patient was ambulatory for 21 years until he developed acute onset of increased drainage and pain necessitating admission for intravenous antibiotics and orthopedic evaluation.

The patient was taken to the operating room (OR) a week after admission where a BKA with posterior skin and muscle

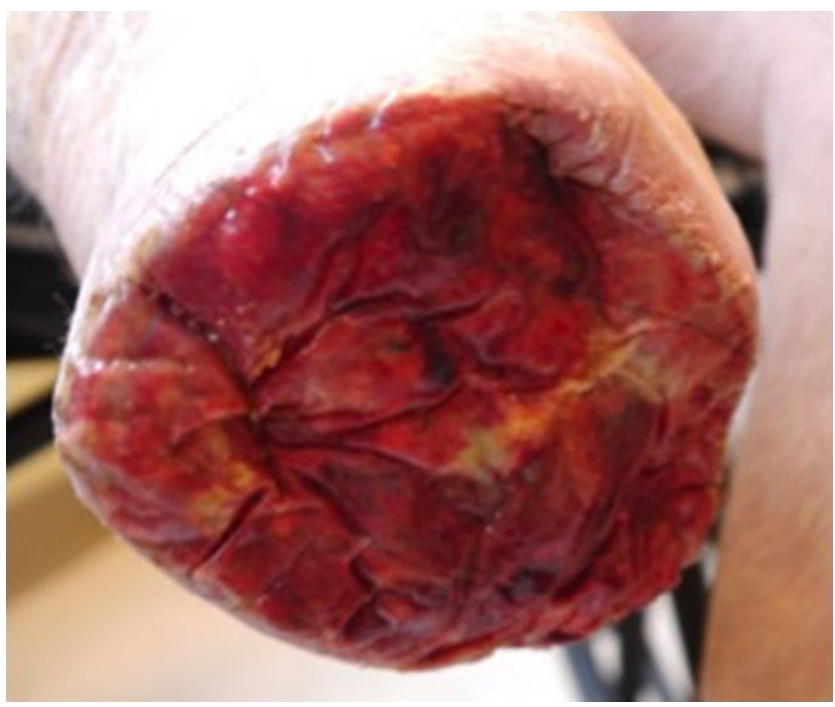

FIG. 2. Image showing the amputation site after multiple washouts and placement of Integra, bi-layer dermal matrix.

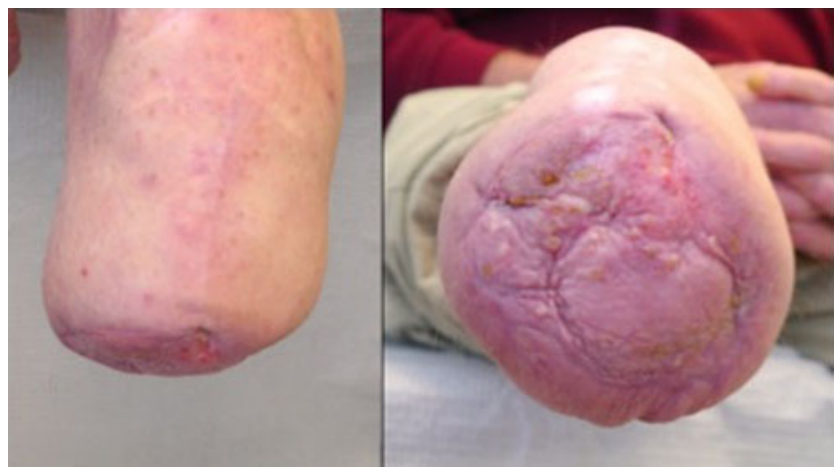

FIG. 3. The amputation stump after interval splitthickness skin grafting.

flap closure was performed. Biopsy specimens revealed welldifferentiated squamous cell carcinoma, and cultures of the distal tibia showed $P$. aeruginosa. The patient remained on doripenam until discharge nine days later and was then sent home with three weeks of daptomycin. In clinic follow-up, the wound broke down despite serial debridement and wound vacuum-assisted closure (VAC) placement (KCI, San Antonio, TX). The patient returned to the OR for debridement of

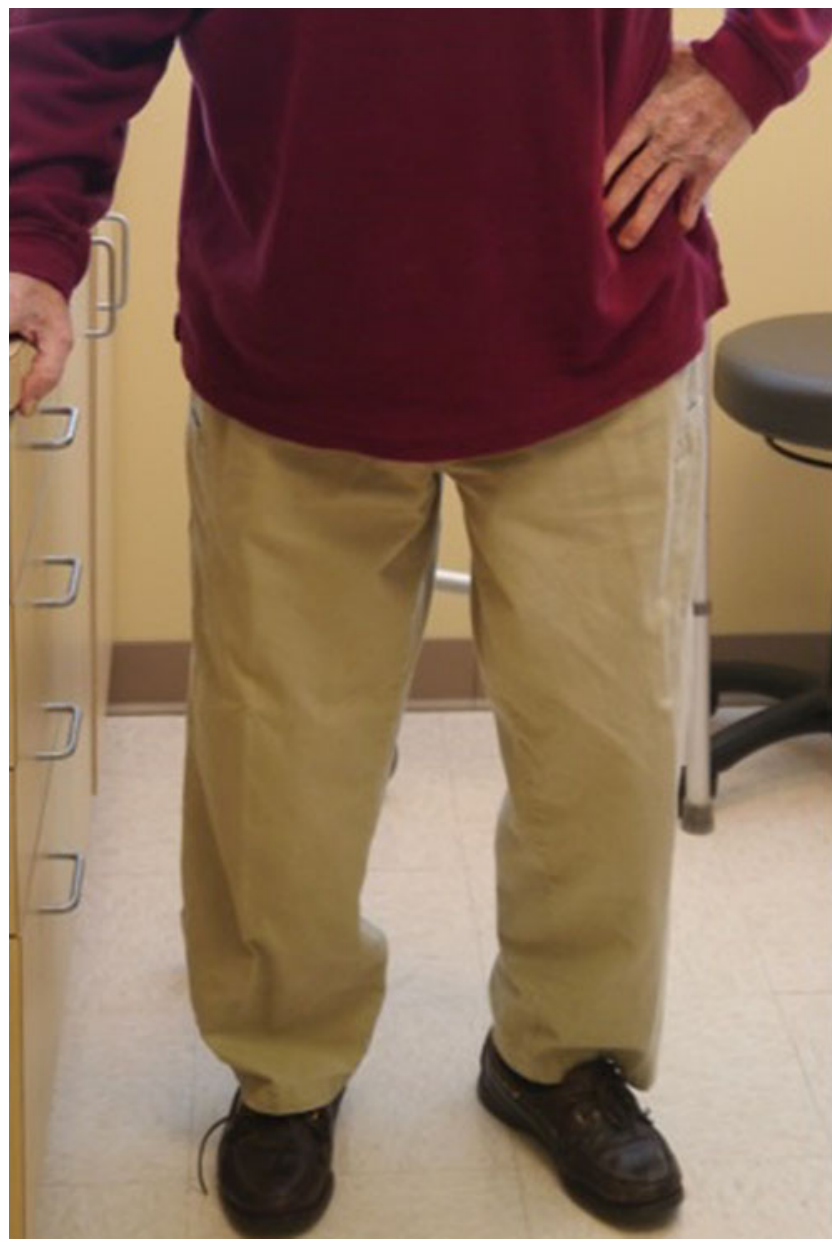

FIG. 4. The patient ambulating to clinic on his prosthetic limb. 
Table 1. Reduction of Microorganisms from Baseline (Log Reduction/Percent Reduction)

\begin{tabular}{|c|c|c|c|}
\hline Bacteria & 1 Minute & 5 Minutes & 30 Minutes \\
\hline $\begin{array}{l}\text { Pseudomonas aeroginosa } \\
\text { (ATCC 27853) } \\
\text { Initial Count }-6.8 \mathrm{E}+08\end{array}$ & $\begin{array}{c}>10-6 \\
>99.9999 \%\end{array}$ & $\begin{array}{c}>10-6 \\
>99.9999 \%\end{array}$ & $\begin{array}{c}>10-6 \\
>99.9999 \%\end{array}$ \\
\hline $\begin{array}{l}\text { Pseudomonas aeroginosa } \\
\text { (SCI) } \\
\text { Initial Count }-1.59 \mathrm{E}+09\end{array}$ & $\begin{array}{c}>10-6 \\
>99.9999 \%\end{array}$ & $\begin{array}{c}>10-7 \\
>99.99999 \%\end{array}$ & $\begin{array}{c}>10-7 \\
>99.99999 \%\end{array}$ \\
\hline $\begin{array}{l}\text { Klebsiella pneumonia } \\
\text { (ATCC 10031) } \\
\text { Initial Count }-5.17 \mathrm{E}+08\end{array}$ & $\begin{array}{c}>10-6 \\
>99.9999 \%\end{array}$ & $\begin{array}{c}>10-6 \\
>99.9999 \%\end{array}$ & $\begin{array}{c}>10-6 \\
>99.9999 \%\end{array}$ \\
\hline $\begin{array}{l}\text { Klebsiella pneumonia } \\
\text { (SCI) } \\
\text { Initial Count }-5.10 \mathrm{E}+08\end{array}$ & $\begin{array}{c}>10-6 \\
>99.9999 \%\end{array}$ & $\begin{array}{c}>10-6 \\
>99.9999 \%\end{array}$ & $\begin{array}{c}>10-7 \\
>99.99999 \%\end{array}$ \\
\hline $\begin{array}{l}\text { Enterobacter aerogenes } \\
\text { (SCI) } \\
\text { Initial Count }-7.27 \mathrm{E}+08\end{array}$ & $\begin{array}{c}>10-6 \\
>99.9999 \%\end{array}$ & $\begin{array}{c}>10-6 \\
>99.9999 \%\end{array}$ & $\begin{array}{c}>10-7 \\
>99.99999 \%\end{array}$ \\
\hline $\begin{array}{l}\text { Escherichia coli } \\
\text { (SCI-1) } \\
\text { Initial Count }-6.37 \mathrm{E}+08\end{array}$ & $\begin{array}{c}>10-6 \\
>99.9999 \%\end{array}$ & $\begin{array}{c}>10-6 \\
>99.9999 \%\end{array}$ & $\begin{array}{c}>10-6 \\
>99.9999 \%\end{array}$ \\
\hline $\begin{array}{l}\text { Escherichia coli } \\
\text { (SCI-2) } \\
\text { Initial Count }-6.17 \mathrm{E}+08\end{array}$ & $\begin{array}{c}>10-6 \\
>99.9999 \%\end{array}$ & $\begin{array}{c}>10-6 \\
>99.9999 \%\end{array}$ & $\begin{array}{c}>10-6 \\
>99.9999 \%\end{array}$ \\
\hline $\begin{array}{l}\text { Acinetobacter baumannii } \\
\text { (SCI-2) } \\
\text { Initial Count }-7.60 \mathrm{E}+08\end{array}$ & $\begin{array}{c}>10-6 \\
>99.9999 \%\end{array}$ & $\begin{array}{c}>10-6 \\
>99.9999 \%\end{array}$ & $\begin{array}{c}>10-6 \\
>99.9999 \%\end{array}$ \\
\hline $\begin{array}{l}\text { Staphylococcus aureus (MRSA) } \\
\text { (SCI) } \\
\text { Initial Count }-4.80 \mathrm{E}+08\end{array}$ & $\begin{aligned} & >10-5 \\
> & 99.999 \%\end{aligned}$ & $\begin{array}{c}>10-6 \\
>99.9999 \%\end{array}$ & $\begin{array}{l}>10-6 \\
>99.9999 \%\end{array}$ \\
\hline $\begin{array}{l}\text { Staphylococcus aureus (MSSA) } \\
\text { (SCI) } \\
\text { Initial Count }-2.54 \mathrm{E}+08\end{array}$ & $\begin{aligned} & >10-5 \\
> & 99.999 \%\end{aligned}$ & $\begin{array}{c}>10-6 \\
>99.9999 \%\end{array}$ & $\begin{array}{c}>10-7 \\
>99.99999 \%\end{array}$ \\
\hline $\begin{array}{l}\text { Enterococcus faecium } \\
\text { (Vancomycin Resistant-1, SCI) } \\
\text { Initial Count }-1.7 \mathrm{E}+09\end{array}$ & $\begin{array}{l}>10-4 \\
>99.99 \%\end{array}$ & $\begin{array}{l}>10-5 \\
>99.999 \%\end{array}$ & $\begin{array}{c}>10-6 \\
>99.9999 \%\end{array}$ \\
\hline $\begin{array}{l}\text { Enterococcus faecium } \\
\text { (Vancomycin Resistant-2, SCI) } \\
\text { Initial Count }-4.2 \mathrm{E}+08\end{array}$ & $\begin{array}{l}>10-4 \\
>99.99\end{array}$ & $\begin{aligned} & >10-5 \\
> & 99.999 \%\end{aligned}$ & $\begin{array}{l}>10-6 \\
>99.9999 \%\end{array}$ \\
\hline $\begin{array}{l}\text { Enterococcus faecium } \\
\text { (Vancomycin Sensitive-1, SCI) } \\
\text { Initial Count }-1.51 \mathrm{E}+08\end{array}$ & $\begin{array}{l}>10-4 \\
>99.99 \%\end{array}$ & $\begin{aligned} & >10-5 \\
> & 99.999 \%\end{aligned}$ & $\begin{array}{l}>10-6 \\
>99.9999 \%\end{array}$ \\
\hline $\begin{array}{l}\text { Enterococcus faecium } \\
\text { (Vancomycin Sensitive-2, SCI) } \\
\text { Initial Count }-7.0 \mathrm{E}+08\end{array}$ & $\begin{array}{l}>10-4 \\
>99.99 \%\end{array}$ & $\begin{aligned} & >10-5 \\
> & 99.999 \%\end{aligned}$ & $\begin{array}{c}>10-6 \\
>99.9999 \%\end{array}$ \\
\hline $\begin{array}{l}\text { Streptococcus pyogenes } \\
\text { (SCI) } \\
\text { Initial Count }-8.8 \mathrm{E}+07\end{array}$ & $\begin{array}{l}>10-4 \\
>99.99 \%\end{array}$ & $\begin{aligned} & >10-5 \\
> & 99.999 \%\end{aligned}$ & $\begin{array}{c}>10-6 \\
>99.9999 \%\end{array}$ \\
\hline $\begin{array}{l}\text { Staphylococcus epidermidis } \\
\text { (ATCC 35984, RP-62) } \\
\text { Biofilm forming organism } \\
\text { Initial Count }-2.02 \mathrm{E}+08\end{array}$ & $\begin{array}{c}>10-6 \\
>99.9999 \%\end{array}$ & $\begin{array}{c}>10-6 \\
>99.9999 \%\end{array}$ & $\begin{array}{c}>10-6 \\
>99.9999 \%\end{array}$ \\
\hline $\begin{array}{l}\text { Staphylococcus epidermidis } \\
\text { (ATCC 14990) } \\
\text { Initial Count }-1-.33 \mathrm{E}+08\end{array}$ & $\begin{aligned} & >10-5 \\
> & 99.999 \%\end{aligned}$ & $\begin{array}{c}>10-6 \\
>99.9999 \%\end{array}$ & $\begin{array}{c}>10-6 \\
>99.9999 \%\end{array}$ \\
\hline $\begin{array}{l}\text { Staphylococcus epidermidis } \\
\text { (SCI) } \\
\text { Initial Count }-1.24 \mathrm{E}+08\end{array}$ & $\begin{aligned} & >10-5 \\
> & 99.999 \%\end{aligned}$ & $\begin{array}{c}>10-6 \\
>99.9999 \%\end{array}$ & $\begin{array}{c}>10-6 \\
>99.9999 \%\end{array}$ \\
\hline
\end{tabular}

Edmiston et al. 2012 [11]. 
soft tissue and bone, and placement of a new wound VAC. Cultures from this operation grew methicillin resistant Staphylococcus aureus and Clostridium perfringens. Plastic surgery was consulted at that time to evaluate a $14 \mathrm{~cm} \times 16$ $\mathrm{cm}$ open wound with necrotic muscle, frank pus, and exposed bone. There was a faint popliteal pulse and $14 \mathrm{~cm}$ of tibial bone; therefore, the decision was made to continue with serial washouts, debridement of tissue and the tibia, and possible closure versus skin grafting in the future.

The patient was again taken to the OR two days after plastic consult for an operative debridement, immersion in chlorhexidine gluconate irrigation (IrriSept, IrriMax Corporation, Lawrenceville, GA), and wound VAC placement. After repeated bedside VAC dressing changes and IrriSept lavage, we noted vast improvement and decided to attempt salvage with bi-layer dermal matrix grafting. The patient was taken back to the OR five days later and underwent repeat debridement, immersion in IrriSept irrigation, and placement of Integra dermal matrix and a wound VAC. He was subsequently discharged with intravenous (IV) antibiotics and weekly office VAC dressing changes to monitor progress (Fig. 2).

Four weeks later, the patient returned to the OR for gentle debridement of his $12 \mathrm{~cm} \times 12 \mathrm{~cm}$ incision and placement of a split-thickness skin graft. He was discharged the same day, and since has healed his stump with durable soft tissue coverage out to 12 months (Fig. 3). He now ambulates to clinic on a prosthetic limb (Fig. 4).

\section{Discussion}

The conversion of chronic osteomyelitis to squamous cell carcinoma is a relatively rare event that often occurs decades after the primary insult. Prevention and early clinical diagnosis can lead to limb salvage; however, once seeded, the customary treatment is amputation of the affected extremity [5]. Cancer recurrence is rare after amputation; however, proximal migration of the bony infection is common.

Amputation below the knee is superior to above the knee in mortality and functional outcomes. However, infection and re-operations in BKAs are more common as the distally based tissues often have diminished perfusion, particularly in patients with a history of vascular disease. Patients that develop osteomyelitis of the tibia suffer from an additional risk of increased infection because of the proximity of the operative field. Post-operative infection in a below-knee stump is the greatest risk factor for conversion to a greaterlevel amputation [6].

The management of a failing BKA should aim to salvage the knee joint; thus, the reconstructive ladder is employed to preserve length and function. The ladder progresses from healing by secondary intention, primary closure, coverage by skin grafting, and up to local rotation flaps versus free tissue coverage [7]. Dermal matrices are a new step in this ladder between primary closure and skin grafting, and they have become a staple in reconstructive operations as they allow for creation of a new tissue layer without a donor site. This option is preferable to local and free tissue transfer in patients with poor in-flow or co-morbidities precluding a long operation.

Integra $^{\mathrm{TM}}$ is a bi-laminar dermal matrix (DM) composed of bovine collagen and a glucosaminoglycan inner layer and a silicone sheet outer layer. Studies have shown the creation of near normal dermis in a previous scar bed treated with Integra DM. After a three- to four-week interval to allow for native tissue in-growth, the neo-dermis within the Integra graft can be covered with a thin split-thickness skin graft or allowed to close secondarily. An essential factor for successful DM engraftment is an infection-free wound bed [8].

Chlorhexidine gluconate $(\mathrm{CHG})$ is the most effective surgical site preparation [9]. CHG is effective against a broad spectrum of Gram negative and Gram positive bacteria, yeast, and even certain viruses. The method of action is cationic binding to the negatively charged cell wall of the target organism. Chlorhexidine gluconate is bacteriostatic at low concentrations by causing an efflux of potassium from the cell, while at high concentrations the cell wall is completely broken apart. The FDA has cleared IrriSept, a $0.05 \%$ CHG solution, for use as intra-operative irrigation. Studies from the Medical College of Wisconsin show a greater than four-fold, log reduction in 18 of the most common bacteria when exposed to IrriSept (Table 1). Leaders of infection prevention and epidemiology have endorsed the use of $\mathrm{CHG}$ to reduce the risk of deep and superficial surgical site infections [10], and IrriSept irrigation is now standard irrigation at the authors' hospital.

\section{Conclusion}

This case report highlights points about chronic infections, DMs, CHG operative irrigation, and a change in clinical algorithm when faced with a grossly contaminated wound in a challenging patient. Multiple bacteria (Escherichia, Pseudomonas, Clostridium, and MRSA) had seeded in the tibia despite previous rounds of antibiotics, and it is of little surprise the patient developed both squamous cell carcinoma and a post-operative infection. In this case, the salvage of his knee joint was dependent equally on surgical debridement, intravenous antibiotics, and chlorhexidine irrigation as it is on DM engraftment. In our previous experience, soft tissue coverage and definitive surgical site infection closure with Integra fails when the surgeon is unable to establish a clean wound. Failure with Integra grafting often leads to AKAs as this patient, and a majority of amputation patients, are not candidates for free tissue transfer. The adoption of chlorhexidine irrigation to the clinical algorithm has aided greatly in eradication of infection, DM engraftment, and salvage of lower extremity wounds. Fortunately, this patient is now infection free and ambulating on a prosthetic limb.

\section{Author Disclosure Statement}

No competing financial interests exist.

\section{References}

1. Taylor SM, Kalbaugh CA, Cass AL, et al. "Successful outcome" after below-knee amputation: An objective definition and influence of clinical variables. Amer Surg 2008; 74:607-612.

2. Ploeg AJ, Lardenoye JW, Vrancken Peeters MP, et al. Contemporary series of morbidity and mortality after lower limb amputation. Eur J Vasc Endovasc Surg 2005;29:633637. 
3. Tang PC, Ravji K, Key JJ, et al. Let them walk! Current prosthesis options for leg and foot amputees. J Amer Coll Surg 2008;206:548-560.

4. Stasik CN, Berceli SA, Nelson PR, et al. Functional outcome after redo below-knee amputation. World J Surg 2008;32:1823-1826.

5. Alami M, Mahfoud M, El Bardouni A, et al. Squamous cell carcinoma arising from chronic osteomyelitis. Acta Ortho Trauma Turcica 2011;45:144-148.

6. Rosen N, Gigi R, Haim A, et al. Mortality and reoperations following lower limb amputations. IMAJ 2014;16:83-87.

7. Fleming ME, O'Daniel A, Bharmal H, et al. Application of the orthoplastic reconstructive ladder to preserve lower extremity amputation length. Ann Plas Surg 2014;73:183-189.

8. Iorio ML, Goldstein J, Adams M, et al. Functional limb salvage in the diabetic patient: The use of a collagen bilayer matrix and risk factors for amputation. Plas Recon Surg 2011;127:260267.

9. Saltzman MD, Nuber GW, Gryzlo SM, et al. Efficacy of surgical preparation solutions in shoulder surgery. J Bone Joint Surg (Amer Vol) 2009;91:1949-1953.

10. Barnes S, Spencer M, Graham D, et al. Surgical wound irrigation: A call for evidence-based standardization of practice. Amer J Infect Cont 2014;42:525-529.

11. Edmiston et al. 2012. Surgical Microbiology Research Laboratory, Medical College of Wisconsin, Milwaukee, Wisconsin.
Address correspondence to: Dr. Hunter R. Moyer Atlanta Plastic Surgery

975 Johnson Ferry Road NE, Suite 100

Atlanta, GA 30342

E-mail: hmoyer@emory.edu

$\begin{aligned} & \text { Abbreviations Used } \\ \mathrm{AKA} & =\text { above-knee amputation } \\ \mathrm{BKA} & =\text { below-knee amputation } \\ \mathrm{CHG} & =\text { chlorhexidine gluconate } \\ \mathrm{DM} & =\text { dermal matrix } \\ \mathrm{IV} & =\text { intravenous } \\ \mathrm{OR} & =\text { operating room } \\ \mathrm{VAC} & =\text { vacuum-assisted closure }\end{aligned}$

Cite this article as: Moyer HR and Minter J (2016)

Salvage of an infected below-knee amputation with chlorhexidine and bi-layer dermal matrix: A case report, Surgical Infections Case Reports 1:1, 47-51, DOI: $10.1089 /$ crsi.2016.0007. 